\title{
Pulmonary Function, Functional Exercise Capacity and Quality of Life in Chemical Dependents in Rehabilitation Process
}

\section{Função Pulmonar, Capacidade Funcional de Exercício e Qualidade de Vida de Dependentes Químicos em Processo de Reabilitação}

\author{
Diery Fernandes Rugila ${ }^{\mathrm{a}}$; Amanda Velozo Rodrigues Luz; ${ }^{\mathrm{b}}$ Natielly Soares Correia ${ }^{\mathrm{a}}$; Jaqueline Stephani Gomes da
} Silva $^{\text {b; Denner Ildemar Feitosa de Melo }}$; Thamyres Spositon ${ }^{\text {bc }}$; Joice Mara de Oliveira ${ }^{\text {bc }}$; Karina Couto Furlanetto*ac

\author{
${ }^{a}$ Unopar, Stricto Sensu Graduate Program in Rehabilitation Sciences. PR, Brazil. \\ bUnopar, Research and Post-Graduate Center, PR, Brazil. \\ 'Universidade Estadual de Londrina, Research Laboratory in Pulmonary Physiotherapy. PR, Brazil. \\ *E-mail: ka_furlanetto@hotmail.com
}

\begin{abstract}
The use of illicit substances can lead to several changes in physical and mental health, which can directly reflect on functional capacity and quality of life. However, there is a lack in the literature on the comparison of these variables between drug addicts and healthy individuals. To compare lung function, functional exercise capacity and quality of life of chemical dependents in rehabilitation process (CDRP) and apparently healthy individuals (AHI). Cross-sectional study that evaluated two groups (CDRP and AHI) matched by gender, age and BMI. Both groups were assessed for lung function (spirometry), quality of life (Short Form 36 questionnaire - SF-36), functional exercise capacity (6-minute walk test - 6MWT, 4-meter gait speed, Timed-up-and-go, Sit-to-Stand and Short Physical Performance Battery). Fifteen men in the CDRP group (31[26-39] years; BMI $23 \pm 3 \mathrm{~kg} / \mathrm{m}^{2}$ ) and fifteen men in the AHI group (30[22-34] years; BMI $24 \pm 3 \mathrm{~kg} / \mathrm{m}^{2}$ ) were analyzed. The CDRP group had a shorter distance covered in the 6MWT in meters $(P=0.0002)$ and percentage of predicted $(P=0.005)$. There was no difference in the performance of the other functional tests $(P \geq 0.20)$ and in the pulmonary function $(P \geq 0.46)$. The CDRP group had worse results in the functional capacity, pain, social aspects and mental health domains of SF-36 $(P \leq 0.04)$, while in the domains general status, vitality, emotional and physical aspects there was no difference $(P \geq 0.08)$. CDRP present similar lung function to AHI. However, the first have impaired functional exercise capacity, as well as some aspects of quality of life.
\end{abstract}

Keywords: Drug Users. Motor Activity. Spirometry. Walk Test. Quality of Life.

\section{Resumo}

O uso de substâncias ilícitas pode levar a diversas alterações da saúde física e mental, o que pode refletir diretamente na capacidade funcional e na qualidade de vida. Porém, há uma escassez na literatura sobre a comparação dessas variáveis entre dependentes químicos e indivíduos saudáveis. Comparar função pulmonar, capacidade funcional de exercício e qualidade de vida de dependentes químicos em processo de reabilitação (DQPR) e indivíduos aparentemente saudáveis (AS). Estudo transversal que avaliou dois grupos (DQPR e AS) pareados por gênero, idade e IMC. Ambos os grupos foram avaliados quanto à função pulmonar (espirometria), qualidade de vida (questionário Short Form 36 - SF36), capacidade funcional de exercício (Teste de Caminhada de 6 minutos - TC6, 4-metre gait speed, Timed-up-and-go, Sit-to-Stand e Short Physical Performace Battery). Foram analisados 15 homens no grupo DQPR (31[26-39] anos; IMC $\left.23 \pm 3 \mathrm{~kg} / \mathrm{m}^{2}\right)$ e 15 homens no grupo AS (30[22-34] anos; IMC $\left.24 \pm 3 \mathrm{~kg} / \mathrm{m}^{2}\right)$. O grupo DQPR apresentou uma menor distância percorrida no TC6 em metros $(P=0,0002)$ e porcentagem do predito $(P=0,005)$. Não houve diferença no desempenho dos demais testes funcionais $(P \geq 0,20)$ e na função pulmonar $(P \geq 0,46)$. O grupo DQPR apresentou piores resultados nos domínios capacidade funcional, dor, aspectos sociais e saúde mental do SF-36 ( $P \leq 0,04)$, enquanto que nos domínios estado geral, vitalidade, aspectos emocionais e físicos não houve diferença $(P \geq 0,08)$. Homens dependentes químicos em processo de reabilitação apresentam função pulmonar semelhante a indivíduos aparentemente saudáveis. Entretanto, apresentam capacidade funcional de exercício prejudicada, assim como alguns aspectos da qualidade de vida.

Palavras-chave: Usuários de Drogas. Atividade Motora. Espirometria. Teste de Caminhada. Qualidade de Vida.

\section{Introduction}

Currently, the use of illicit drugs is treated as a public health problem. According to the World Health Organization, in 2013, 246 million people used illicit drugs, which corresponds to $5 \%$ of the total world population aged 15 to 64 years, with marijuana and opioids being the most widely used drugs ${ }^{1}$. In a survey conducted in Brazil in 2017, approximately 15 million individuals reported having used illicit drugs ever in life, and 2.5 million reported using them up to thirty days prior to research. Marijuana and cocaine were the most prevalent drugs ${ }^{1}$.
The use of illicit substances can lead to various physical and mental health conditions, such as bloodstream infections and difficulty maintaining interpersonal relationships, respectively. Furthermore, chemical dependence causes around 400 deaths per year ${ }^{1}$.

It is also known that the use of drugs leads to pulmonary morphological alterations, such as parenchymal abnormalities, nodulations, consolidations, air trapping, emphysema, airway burn, bronchial hyperreactivity and pulmonary edema ${ }^{3,4}$. Pulmonary edema is caused mainly by the use of opioids, such as heroin, by mechanisms that are still unknown, but 
it is hypothesized that this type of drug causes systemic inflammation ${ }^{4}$. Other changes are found mainly in crack users due to their preparation and consumption mode ${ }^{4}$. In the case of marijuana, when used in a small amount, it seems not to cause significant respiratory alterations ${ }^{4}$. Although these morphological changes in the respiratory tract are proven, little is known about pulmonary function in these individuals.

In addition to pulmonary alterations, illicit drug users present a reduction in maximum oxygen consumption, worse gait efficiency and lower muscle strength of lower limbs when compared to healthy individuals ${ }^{5}$. At the same time, the longer the time of drug use, the more physical agility and the balance of these individuals are impaired ${ }^{6}$. Since all these physical changes already found in the literature may affect the functionality, the evaluation of the functional exercise capacity of chemical dependents becomes essential. The 6-minute walk test is the most used test to perform this type of evaluation, since it is a simple, fast, low-cost and easy-tounderstand test ${ }^{7}$. However, this test was still little studied in this population ${ }^{8}$.

Quality of life is another aspect that is impaired in users of psychoactive substances $^{9,10}$. Individuals who make use of these substances face difficulty maintaining relationships with their family and friends and difficulty carrying out their works ${ }^{1}$, which can often lead them to social isolation. The feeling of repentance for having started using drugs can also be a factor that impacts on quality of life ${ }^{11}$. The quality of life affected in drug users is already well established in the literature, but the comparison of this variable between chemical dependents and healthy individuals has not been performed yet.

Considering the aspects of pulmonary, physical and mental alterations presented, the objective of this study was to compare pulmonary function, functional exercise capacity and quality of life of chemical dependents in rehabilitation process with apparently healthy individuals.

\section{Material and Methods}

\subsection{Study design and participants recruitment}

This is a cross-sectional study, approved by the Research Ethics Committee of Universidade Pitágoras-UNOPAR (2.009.139), in which Brazilian individuals who signed the Free and Informed Consent Form were included to attend the research. The study inclusion criteria were: age between 18 and 80 years, ability to understand and perform the proposed evaluations and absence of diseases and/or conditions that could limit the evaluations. The normal pulmonary function, evaluated by spirometry, was a criterion for inclusion only for individuals without a history of illicit drug use. Those with body mass index (BMI) lower than $18 \mathrm{~kg} / \mathrm{m}^{2}$ and greater than $40 \mathrm{~kg} / \mathrm{m}^{2}$ were excluded and those who did not perform the proposed assessments for any reason were excluded.

Two groups of male participants were identified and compared, one composed of chemical dependents in rehabilitation process (CDRP group) of illicit drugs and the other composed of apparently healthy individuals (AHI group). These groups were matched by gender, age and BMI. In this study, the participants recruitment of the AHI group took place through an invitation to the researchers' relatives and friends involved in the study, as well as employees and students of the institution. On the other hand, the recruitment of the CDRP participants group took place through an invitation to the individuals who were treated at Casa Verde Rehabilitation Institution in Londrina-PR, which only serves men and does not offer medicines for treatment, but offers a separation from society and from the means of drugs induction, providing a rehabilitation method through religion for a period of six months. Individuals also perform manual work within the institution, attend classes, participate in games and physical activities.

Individuals from both groups underwent evaluations of general and anthropometric data, pulmonary function (spirometry), quality of life (Medical outcomes study 36item short form Health Survey), functional exercise capacity (6-minute walk test, 4-meter gait speed at usual speed, Timedup-and-go at usual speed, 1-minute Sit-to-Stand, and Short Physical Performance Battery). In addition, the CDRP group also responded to a chemical dependence questionnaire, Alcohol, Smoking and Substance Involvement Screening Test.

\subsection{General and Anthropometric Data}

For anthropometric assessment, weight and height were measured with a scale and stadiometer (Ítaca Com. Equip. LTDA; model MIC2/BA of São Paulo - SP, respectively). Body mass index (BMI) was determined by means of the calculation: weight/height. In addition, the age record was performed and the CDRP group recorded how many days the participants were without using illicit drugs.

\subsection{Pulmonary Function - Spirometry}

Pulmonary function was evaluated using a spirometer (Pony FX COSMED). The technique was performed according to the guidelines of the American Thoracic Society (ATS) and European Respiratory Society (ERS) ${ }^{12}$, determining the forced expiratory volume in one second $\left(\mathrm{FEV}_{1}\right)$, forced vital capacity (FVC) and $\mathrm{FEV}_{1} / \mathrm{FVC}$ ratio. The reference values for the Brazilian population were used ${ }^{13}$.

\subsection{Functional Exercise Capacity}

6-minute walk test - 6MWT

6MWT was performed according to ATS/ERS standardization ${ }^{7}$. The individuals were instructed to walk and travel as far as possible in 6 minutes in a 30-meter flat corridor. Two tests were performed with a minimum interval of 30 minutes between them and the highest value in meters was used for the analyzes. The reference values for the Brazilian population ${ }^{14}$ were used to calculate the percentage 
of the predicted values reached during the test

\section{4-meter gait speed (4MGS)}

Two cones were positioned 4 meters away and the individuals were instructed to walk at a comfortable/normal rhythm from one cone to the other from the "go" command ${ }^{15}$. The time, in seconds, spent to walk 4 meters was marked by a stopwatch.

\section{Timed-up-and-go (TUG)}

The patient was instructed to stand up from a chair from the "go" command, walk in a 3-m straight line marked on the ground at a comfortable and safe speed, turn around, walk back to the chair and $\mathrm{sit}^{16}$. A 46-cm-high chair with arm support was used and individuals were instructed to start the test with full support of the dorsal spine at the back and the upper limbs supported in the chair arms. The time, in seconds, used to perform the entire test path was marked by a stopwatch ${ }^{16}$.

Sit-to-stand 1 min (STS 1min)

STS 1 min was performed using a $46 \mathrm{~cm}$ high chair without support for the upper limbs, resting against the wall for better stabilization. The individuals were instructed to stand and sit as many times as possible within 1 minute from the "go" command. The upper limbs should remain crossed over the trunk and each complete standing movement was accounted for ${ }^{17}$. Short Physical $O$ Short Physical Performance Battery (SPPB)

SPPB was performed according to the protocol by Freire et al. ${ }^{15}$, in which three activities were evaluated: 1) ability to remain in balance on foot for up to 10 seconds on bipodal (side-by-side), semi-tandem and tandem support; 2) total time to complete a 4-meter walk at usual speed (this task was performed twice, in which the best time was used for the total score); 3) time to sit and stand from one chair for 5 consecutive times as fast as possible. The score for each activity ranged from 0 to 4 , reaching a total of a maximum of 12 points $^{14}$.

\subsection{Quality of life - Medical Outcomes Study 36-Item Short Form Health Survey (SF-36)}

The instrument used to evaluate the quality of life was the Portuguese version of the SF-36 questionnaire, which is a generic, multidimensional questionnaire, easy to administer and understand. It has 36 items, encompassing 8 domains: functional capacity, physical aspects, pain, general health status, vitality, social aspects, emotional aspects and mental health. It has a final score of 0-100, in which the higher the score, the better the quality of life related to health ${ }^{18}$.

\subsection{Alcohol, Smoking and Substance Involvement Screening Test (ASSIST)}

ASSIST was used to perform the screening of which substances the participants of CDRP group used before the rehabilitation. This questionnaire is composed of 8 questions that address the use and problems related to several drugs and illicit substances ${ }^{19}$.

\subsection{Statistical Analysis}

For statistical analysis, the Shapiro-Wilk test was used to analyze the data normality. The results were described as mean \pm standard deviation or median [interquartile range 25$75 \%$ ]. The comparisons between the groups were performed using the non-paired t test or the Mann Whitney test, according to the data normality. The statistical software used for the analyzes was GraphPad Prism 6.0 and the level of statistical significance adopted was $\mathrm{P}<0.05$.

\section{Results and Discussion}

15 men were analyzed in the CDRP group and 15 men in the AHI group. There was no statistically significant difference between the groups in the general characteristics $(\mathrm{P} \geq 0.11)$ and in pulmonary function $(\mathrm{P} \geq 0.46)$ (Table 1$)$.

Table 1 - Comparison of general characteristics and pulmonary function between CDPR and AHI groups

\begin{tabular}{|l|l|c|l|}
\hline & $\begin{array}{c}\text { Group } \\
\text { CDRP } \\
(\mathbf{n}=15)\end{array}$ & $\begin{array}{c}\text { Group } \\
\text { AHI } \\
(\mathbf{n}=15)\end{array}$ & $P$-value \\
\hline
\end{tabular}

\section{General characteristics}

\begin{tabular}{|l|c|c|c|}
\hline Age (years) & $31[26-39]$ & $30[22-34]$ & $P=0.31$ \\
\hline Weight $(\mathrm{Kg})$ & $70 \pm 9$ & $76 \pm 12$ & $P=0.11$ \\
\hline BMI $\left(\mathrm{Kg} / \mathrm{m}^{2}\right)$ & $23 \pm 3$ & $24 \pm 3$ & $P=0.22$ \\
\hline Height $(\mathrm{cm})$ & $174 \pm 6 \ldots$ & $177 \pm 7$ & $P=0.28$
\end{tabular}

\section{Pulmonary Function}

\begin{tabular}{|l|c|c|c|}
\hline FEV (\%predicted) & $92 \pm 15$ & $94 \pm 15$ & $P=0.80$ \\
\hline FVC (\%predicted) & $94 \pm 16$ & $94 \pm 12$ & $P=0.86$ \\
\hline FEV / FVC(\%) & $81 \pm 7$ & $83 \pm 9$ & $P=0.46$ \\
\hline
\end{tabular}

Chemical dependents in rehabilitation process (CDRP); AHI: Apparently healthy individuals ; BMI: Body mass index; $\mathrm{FEV}_{1}$ : forced expiratory volume in one second; FVC: Forced vital capacity; FEV $\mathrm{FVV}_{1}$ FV: ratio between forced expiratory volume in one second and forced vital capacity. Source: Research data.

Regarding functional capacity, the CDRP group presented a smaller distance walked in the 6MWT in meters (CDRP) $583 \pm 51 \mathrm{~m}$ vs $671 \pm 67 \mathrm{~m}$; $\mathrm{P}=0.0002$ ) (Figure 1) as well as in percentage of predicted value (CDRP $88 \pm 7 \%$ pred vs $100 \pm 14 \%$ pred; $\mathrm{P}=0.005$ ) (Figure 2 ). There was no statistically significant difference between the groups in the performance of the other functional tests $(\mathrm{P} \geq 0.20)$ (Table 2$)$.

Figures 1 and 2 - Comparison between the Chemical dependents in rehabilitation process (CDRP) and apparently healthy individuals (AHI) groups in the functional exercise capacity evaluated by the 6 -minute walk Test (6MWT) in meters and in percentage of predicted value, respectively

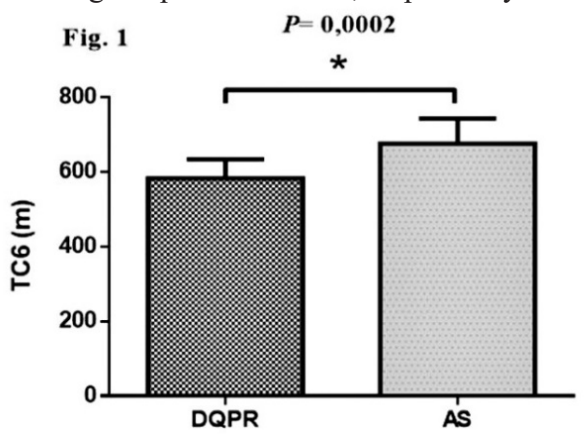




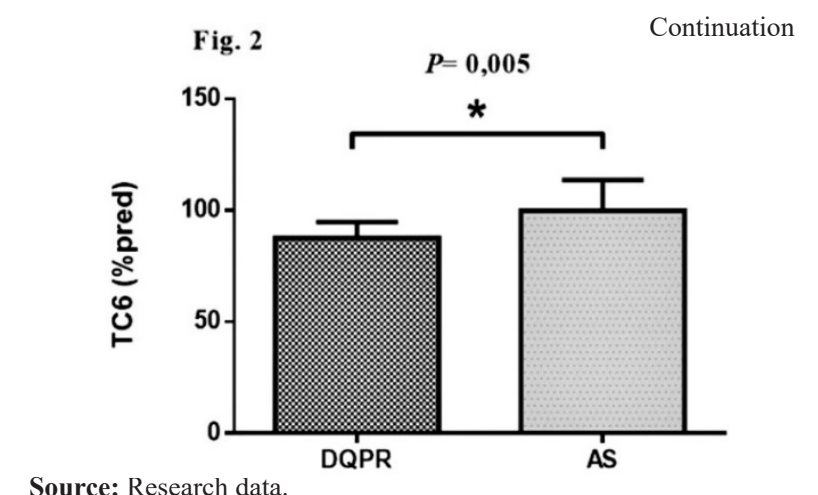

Source: Research data.

Table 2 - Comparison of functional tests between CDPR and AHI groups

\begin{tabular}{|l|c|c|c|}
\hline & $\begin{array}{c}\text { Group } \\
\text { CDRP } \\
(\mathbf{n}=15)\end{array}$ & $\begin{array}{c}\text { Group } \\
\text { AHI } \\
(\mathbf{n}=15)\end{array}$ & $P$-value \\
\hline TUG (seconds) & $5.5 \pm 0.1$ & $5.6 \pm 0.2$ & $P=0.90$ \\
\hline 4MGS (seconds) & $3.9[3.4-4.1]$ & $3.7[3.3-4.1]$ & $P=0.80$ \\
\hline $\begin{array}{l}\text { STS 1min } \\
\text { (repetitions) }\end{array}$ & $37 \pm 3$ & $38 \pm 2$ & $P=0.64$ \\
\hline SPPB (points) & $12[11-12]$ & $12[12-12]$ & $P=0.46$ \\
\hline
\end{tabular}

healthy individuals ; TUG: timed-up-and-go; 4MGS: 4-meter gait speed; STS 1 min: sit-to-stand 1 minute; SPPB: short physical performance battery

Source: Research data

In addition, the CDRP group presented worse quality of life results in the domains social aspects (CDRP 62[50-87] vs. AHI 100[75-100]), mental health (CDRP 72[52-88] vs. AHI 90[75-90] points), functional capacity (CDRP 90[75$100]$ vs. AHI 100[95-100] 84), and pain (CDRP 61 [40-74] vs. AHI 84 [61-84] points), of the SF-36 questionnaire ( $\mathrm{P} \leq 0.04$ for all of them) (Figure 3). On the other hand, in the domains physical aspects (CDRP 100[50-100] vs. AHI 100[93-100] points), vitality (CDRP 80[60-90] vs. AHI 81[75-87] points), general state (CDRP 67[57-82] vs. AHI 82[75-90] points) and emotional aspects (CDRP 100[66-100] vs. AHI 100[100$100]$ points) there was no statistically significant difference between the groups ( $\mathrm{P} \geq 0.08$ for all of them (Figure 4).

Figure 3 - Comparison between the chemical dependents in rehabilitation process (CDRP) and apparently healthy individuals (AHI) in quality of life assessed by the Medical outcomes study 36-Item short form Health Survey in the domains social aspects, mental health, functional capacity and pain

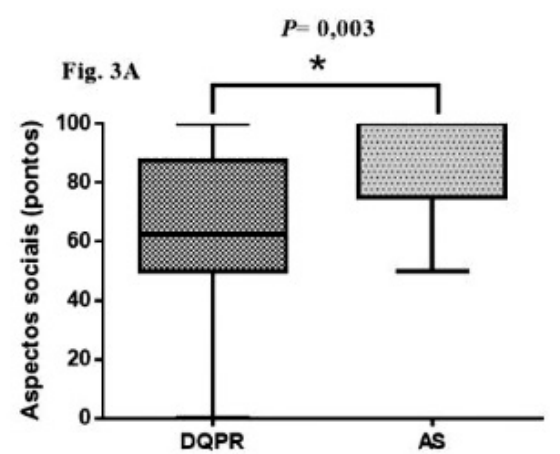

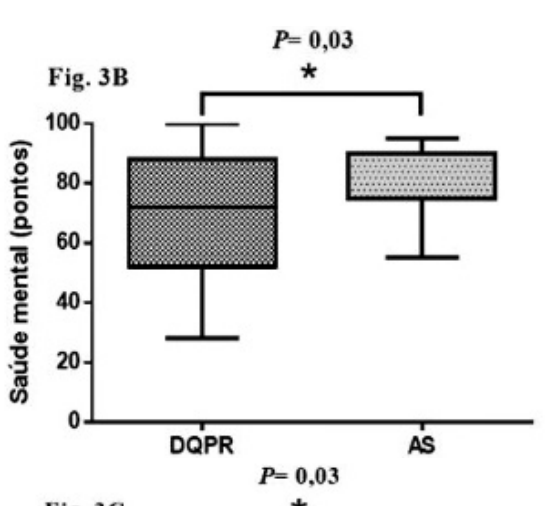

Continuation
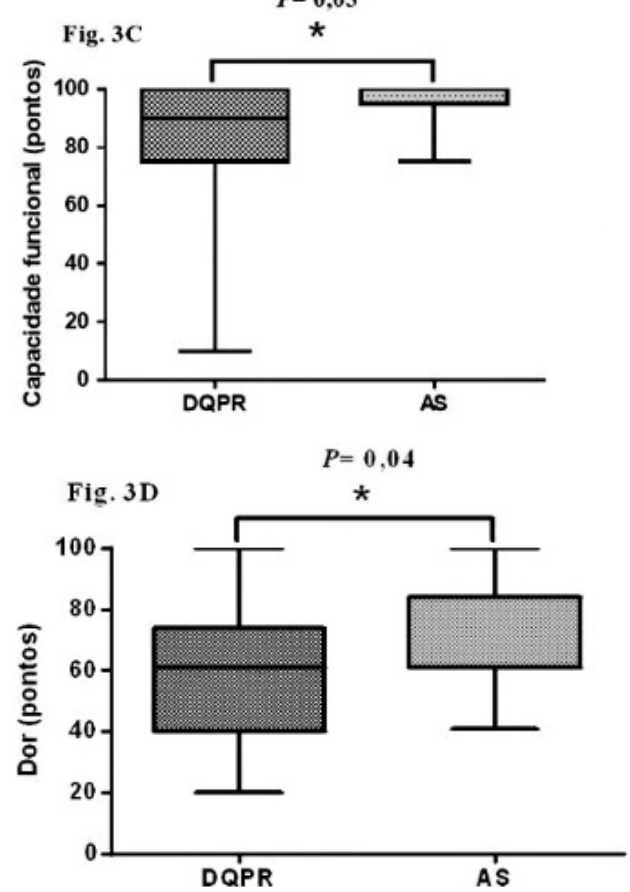

Source: Research data.

Figure 4 - Comparison between the chemical dependents in rehabilitation process (CDRP) and apparently healthy individuals ( $\mathrm{AHI}$ ) in quality of life assessed by the Medical outcomes study 36-Item short form Health Survey in the domains physical aspects, vitality, general state and emotional aspects

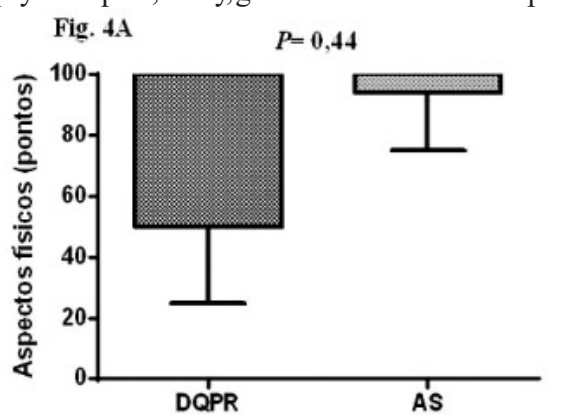

$P=0,62$

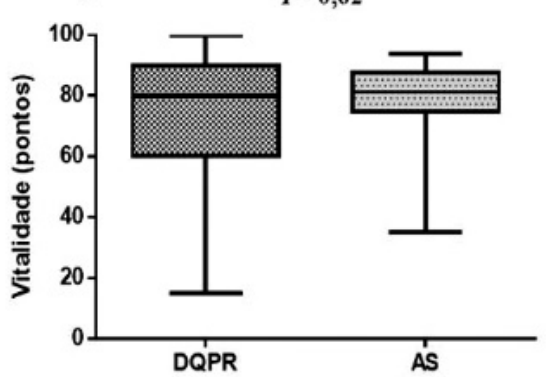




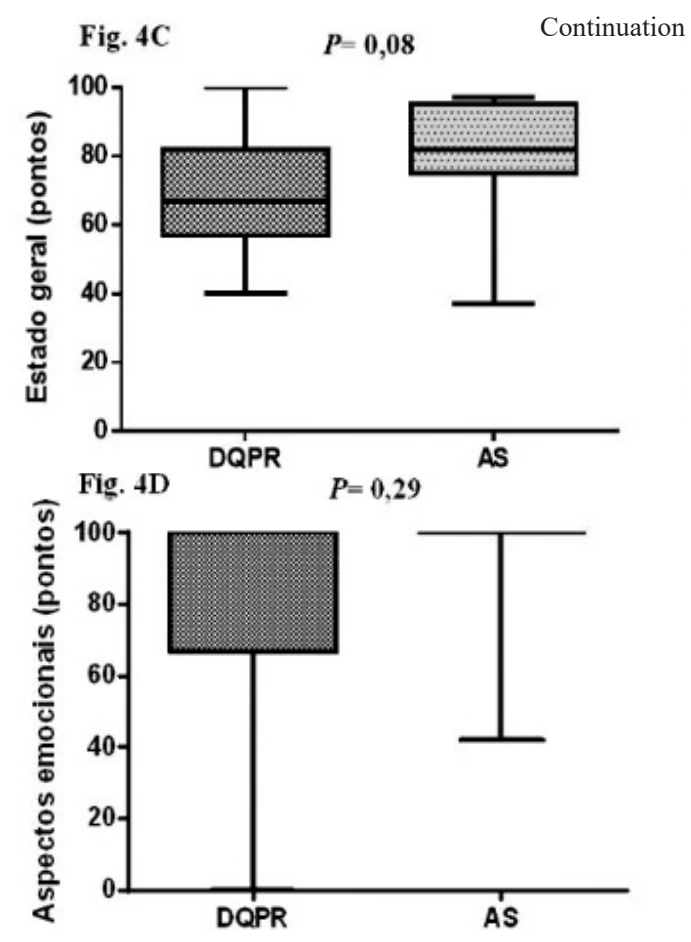

Source: Research data.

The days without using illicit drugs by each participant in the CDRP group and the types of drugs identified by ASSIST are described in Table 3. In this group, 53.3\% of the sample used three or more types of illicit substances, $40 \%$ used two types and only $6.7 \%$ used only one substance. On average, the CDRP group participants were without using drugs for $72 \pm$ 56 days. The drugs most frequently used in the sample were cocaine $(93 \%)$, marijuana $(73 \%)$ and crack $(60 \%)$.

Table 3 - Days without using illicit drugs by the CDRP group and types of drugs identified by ASSIST

\begin{tabular}{|l|c|c|}
\hline & $\begin{array}{c}\text { Days without } \\
\text { using drugs }\end{array}$ & Illicit drugs used \\
\hline Participant 1 & 52 & Ethanol (fuel) \\
\hline Participant 2 & 34 & Cocaine, crack and opioids \\
\hline Participant 3 & 122 & Cocaine and crack \\
\hline Participant 4 & 82 & Cocaine and opioids \\
\hline Participant 5 & 90 & Cocaine, crack and marijuana \\
\hline Participant 6 & 89 & Cocaine, crack and marijuana \\
\hline Participant 7 & 4 & Cocaine and marijuana \\
\hline Participant 8 & 124 & $\begin{array}{c}\text { Cocaine, crack, opioids, } \\
\text { marijuana, hallucinogens }\end{array}$ \\
\hline Participant 9 & 162 & Cocaine and marijuana \\
\hline Participant 10 & 21 & Cocaine, crack and marijuana \\
\hline Participant 11 & 38 & Cocaine, crack and marijuana \\
\hline Participant 12 & 16 & Cocaine and marijuana \\
\hline Participant 13 & 180 & Cocaine and marijuana \\
\hline Participant 14 & 6 & Cocaine, crack and marijuana \\
\hline Participant 15 & 60 & Cocaine, crack and marijuana \\
\hline
\end{tabular}

CDRP: Chemical dependents in rehabilitation process; ASSIST: Alcohol, Smoking and Substance Involvement Screening Test

Source: Research data.

The results of the present study suggest that ex-users of illicit drugs of male sex, when compared to apparently healthy individuals, exhibit preserved pulmonary function; however, they have worse functional exercise capacity and worse quality of life in social aspects, mental health, functional capacity and pain.

In 2016, Palú et al. ${ }^{8}$ suggested that the morphological changes found in the respiratory system of chemical dependents do not reflect the pulmonary function and functional exercise capacity of these individuals. These authors did not make comparisons with a control group and the results of the study were based on the percentage of predicted value achieved in the evaluations. This finding corroborates in parts with the present study, which did not find any difference between the groups in pulmonary function and in the performance of some functional tests, but found a worse functional capacity of exercise in the CDRP group evaluated by the 6MWT, both in the distance traveled in meters and in percentage of the predicted value. Other two studies did not find changes in pulmonary function in individuals who used crack and marijuana ${ }^{20,21}$. Both studies also did not make comparisons with a control group. Thus, the importance of the present study is perceived. It was hypothesized that because the CDRP group is composed of young adult individuals, it is possible that the time of drug use has been small and that this short period of exposure may not have affected the respiratory system enough to lead to changes in pulmonary function, and may not have caused systemic changes in order to cause greater impairment in functional capacity.

O'Brian et al. ${ }^{22}$ found that drug users have five times more chance of presenting low quality of life than non-users. The low quality of life was also found in our sample in some areas of the SF-36 questionnaire. In the study by Marcon et al., psychoactive substance users had the domains emotional aspects, social aspects and mental health with lower scores in the SF- $36^{10}$ questionnaire. These data confirm the results of the present study, in which worse scores were found in the areas of social aspects, mental health, functional capacity and pain, and it is possible to state that former chemical dependents present worse quality of life compared to apparently healthy individuals.

Higher prevalence of cocaine and marijuana use found in the CDRP group sample is in accordance with data from the III National Survey on Drug use by the Brazilian population², which indicates that, despite the small sample, the group may be representative of the general population.

The limitations of this study include: small sample size and composed only of male participants, being a crosssectional study, in which cause and effect cannot be asserted, the CDRP group heterogeneity (each participant used different types of illicit drugs and was at a different time in the rehabilitation process) and no data were collected on how long the individuals used drugs. Despite these limitations, this is the first study to compare pulmonary function, exercise functional capacity and quality of life of chemical dependents with apparently healthy individuals. However, longitudinal 
studies with larger samples are suggested that include participants of both sexes in order to detect when changes in the functional exercise capacity and quality of life found in the present study arise and whether these changes are also found in females.

\section{Conclusion}

Men who have used illicit drugs and are in rehabilitation process have similar pulmonary function when compared to apparently healthy individuals. However, the functional exercise capacity of chemical dependents, evaluated by the $6 \mathrm{MWT}$, is more impaired. In addition, some aspects of quality of life have been worse in this population.

\section{Acknowledgments}

To the study participants and colleagues at the Research and Post-Graduate Center at Universidade Pitágoras -Unopar (UNOPAR) who collaborated with the research. Financial support of Coordenação de Aperfeiçoamento de Pessoal de Nível Superior (CAPES), Conselho Nacional de Desenvolvimento Científico e Tecnológico (CNPq) and Fundação Nacional do Desenvolvimento do Ensino Superior Particular (FUNADESP).

\section{References}

1. WHO - World Health Organization. The World Health Organization: Expanding public health approaches to the world drug problem. 2015. Available from: https://www.who. int/substance_abuse/ungass-leaflet.pdf?ua=1.

2. Bastos FIPM, Vasconcellos MTL, De Boni RB, Reis NB, Coutinho CFS. III Levantamento Nacional sobre o uso de Drogas pela População Brasileira. FIOCRUZ/ICICT. 2017. Available from: https://www.arca.fiocruz.br/handle/ icict/34614.

3. Nguyen ET, Silva IS, Souza CA, Müller NL. Pulmonary complications of illicit drug use: Differential diagnosis based on CT findings. J Thorac Imaging 2007;22(2):199-206. doi: 10.1097/01.rti.0000213567.86408.19.

4. Mégarbane B, Chevillard L. The large spectrum of pulmonary complications following illicit drug use: Features and mechanisms. Chem Biol Interact 2013;206(3):444-51. doi: 10.1016/j.cbi.2013.10.011.

5. Flemmen G, Wang E. Impaired aerobic endurance and muscular strength in substance use disorder patients. Med (United States) 2015;94(44):e1914. doi:10.1097/ MD.0000000000001914.

6. Malagodi B, Greguol M, Serassuelo Junior H. Análise do equilíbrio corporal e aptidão física de indivíduos em tratamento para dependência química. Rev Bras Ativ Fís Saúde 2018;23:1-9. doi:10.12820/rbafs.23e0012.

7. Holland AE, Spruit MA, Troosters T, Puhan MA, Pepin V, Saey D, et al. An official European Respiratory Society /American Thoracic Society technical standard: field walking tests in chronic respiratory disease. Eur Respir J 2014;44(6):1428-46. doi: 10.1183/09031936.00150314.

8. Palú M, Dos Santos K, Scalco JC, Cani KC, Dos Santos JJA. Função pulmonar e capacidade funcional de usuários de drogas ilícitas em processo de desintoxicação. Med 2016;49(2):189-
93. doi:10.11606/issn.2176-7262.v49i2p189-193

9. Marcon SR, Rubira EA, Espinosa MM, Barbosa DA. Quality of life and depressive symptoms among caregivers and drug dependent people. Rev Latinoam Enferm 2012;20(1):167-74. doi:10.1590/s0104-11692012000100022.

10. Marcon SR, Xavier JS, Barcelon AA, Espinosa MM, Barbosa DA. Correlation between depressive symptoms and quality of life in users of psychoactive substances. Rev Esc Enferm 2014;48(4):663-9. doi: 10.1590/s0080623420140000400013 .

11. Roe B, Beynon C, Pickering L, Duffy P. Experiences of drug use and ageing: Health, quality of life, relationship and service implications. J Adv Nurs 2010;66(9):1968-79. doi: 0.1111/j.1365-2648.2010.05378.x.

12. Miller MR, Hankinson J, Brusasco V, Burgos F, Casaburi R, Coates A, et al. Standardisation of spirometry. Eur Respir J 2005;26(2):319-38. doi: 10.1183/09031936.05.00034805.

13. Pereira CA de C, Sato T, Rodrigues SC. New reference values for forced spirometry in white adults in Brazil. J Bras Pneumol 2007;33(4):397-406. doi:10.1590/S180637132007000400008 .

14. Britto RR, Probst VS, Dornelas de Andrade AF, Samora GAR, Hernandes NA, Marinho PEM, et al. Reference equations for the six-minute walk distance based on a Brazilian multicenter study. Brazilian J Phys Ther 2013;17(6):556-63. doi:10.1590/ S1413-35552012005000122.

15. Freire AN, Guerra RO, Alvarado B, Guralnik JM, Zunzunegui MV. Validity and reliability of the short physical performance battery in two diverse older adult populations in Quebec and Brazil. J Aging Health 2012;24(5):863-78. doi: 10.1177/0898264312438551.

16. Podsiadlo D, Richardson S. The Timed "Up \& Go": a test of basic functional mobilitv for frail elderlv persons. J Am Geriatr Soc 1991;39(2):142-8. doi: 10.1111/j.15325415.1991.tb01616.x.

17. Bohannon RW, Crouch R. 1-Minute Sit-To-Stand Test: Systematic review of procedures, performance and clinimetric properties. J Cardiopulm Rehabil Prev 2019;39(1):2-8. doi: 10.1097/HCR.0000000000000336.

18. Ciconelli RM, Ferraz MB, Santos W, Meinao I, Quaresma MR. Brazilian-Portuguese version of the SF-36. A reliable and valid quality of life outcome measure. Rev Bras Reumatol 1999;39(3):143-50.

19. Barbor TE. The Alcohol, Smoking and Substance Involvement Screening Test (ASSIST): development, reliability and feasibility. Addiction 2002;97:1183-94. doi:10.1 111/j.13600443.2007.02114.x.

20. Peres PCN, Cian MJ, Grandi TR, Antunes MD, Bertolini SMMG. Avaliação da função pulmonar e força muscular respiratória de dependentes químicos em tratamento. ConScientiae Saúde 2018;17(1):25-31. doi: 10.5585/ conssaude.v17n1.7504.

21. Pletcher MJ, Vittinghoff E, Kalhan R, Richman J, Safford $\mathrm{M}$, Sidney S, et al. Association between marijuana exposure and pulmonary function over 20 years. JAMA - J Am Med Assoc Am Med Assoc 2012;307(2):173-81. doi: 10.1001/ jama.2011.1961.

22. O’Brien KK, Schuttke A, Alhakeem A, Donnelly-Swift E, Keogh C, O'Carroll A, et al. Health, perceived quality of life and health services use among homeless illicit drug users. Drug Alcohol Depend 2015;154:139-45. doi: 10.1016/j. drugalcdep.2015.06.033, 